"Thought provoking and fresh - this book challenges how we think about economics."

GILLIAN TETT, Financial Times

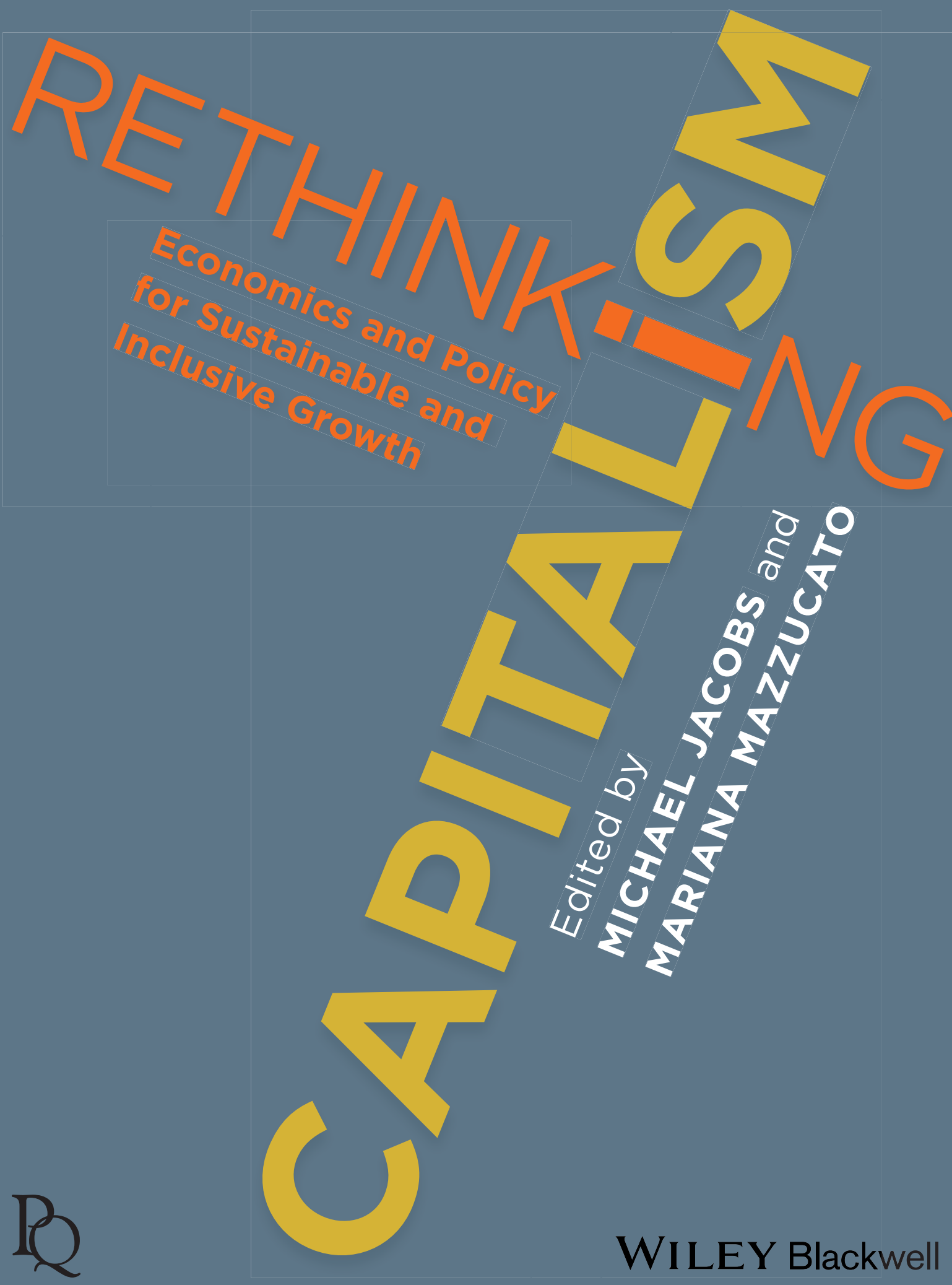




\section{RETHINKING CAPITALISM}

Economics and Policy for Sustainable and Inclusive Growth 



\section{RETHINKING CAPITALISM}

Economics and Policy for Sustainable and Inclusive Growth

Edited by

Michael Jacobs and Mariana Mazzucato

Wiley-Blackwell

In association with The Political Quarterly 
This edition first published 2016

(C) 2016 The Political Quarterly Publishing Co. Ltd except for editorial material

Blackwell Publishing was acquired by John Wiley \& Sons in February 2007. Blackwell's publishing programme has been merged with Wiley's global Scientific, Technical and Medical business to form Wiley-Blackwell.

Registered Office

John Wiley \& Sons Ltd, The Atrium, Southern Gate, Chichester, West Sussex, PO19 8SQ,

United Kingdom

Editorial Offices

350 Main Street, Malden, MA 02148-5020, USA

9600 Garsington Road, Oxford, OX4 2DQ, UK

The Atrium, Southern Gate, Chichester, West Sussex, PO19 8SQ, UK

For details of our global editorial offices, for customer services, and for information about how to apply for permission to reuse the copyright material in this book please see our website at www.wiley.com/wiley-blackwell.

The rights of Michael Jacobs and Mariana Mazzucato to be identified as the editor of the editorial material in this work has been asserted in accordance with the Copyright, Designs and Patents Act 1988.

All rights reserved. No part of this publication may be reproduced, stored in a retrieval system, or transmitted, in any form or by any means, electronic, mechanical, photocopying, recording or otherwise, except as permitted by the UK Copyright, Designs and Patents Act 1988, without the prior permission of the publisher.

Wiley also publishes its books in a variety of electronic formats. Some content that appears in print may not be available in electronic books. Designations used by companies to distinguish their products are often claimed as trademarks. All brand names and product names used in this book are trade names, service marks, trademarks or registered trademarks of their respective owners. The publisher is not associated with any product or vendor mentioned in this book.

Limit of Liability/Disclaimer of Warranty: While the publisher and authors have used their best efforts in preparing this book, they make no representations or warranties with respect to the accuracy or completeness of the contents of this book and specifically disclaim any implied warranties of merchantability or fitness for a particular purpose. It is sold on the understanding that the publisher is not engaged in rendering professional services and neither the publisher nor the authors shall be liable for damages arising herefrom. If professional advice or other expert assistance is required, the services of a competent professional should be sought.

First published in 2016 by John Wiley \& Sons

Library of Congress Cataloging-in-Publication Data

Names: Jacobs, Michael, 1960- editor. I Mazzucato, Mariana, 1968- editor.

Title: Rethinking capitalism : economics and policy for sustainable and inclusive growth / edited by Michael Jacobs and Mariana Mazzucato.

Description: Chichester, West Sussex, United Kingdom : Wiley-Blackwell, in association with The Political Quarterly, 2016. I Includes bibliographical references.

Identifiers: LCCN 2016024733 | ISBN 9781119120957 (pbk. : alk. paper)

Subjects: LCSH: Capitalism. I Sustainable development. I Economic development--Environmental aspects.

Classification: LCC HB501 .R4295 2016 | DDC 330.12/2--dc23 LC record available at https:/ /lccn.loc.gov/2016024733

Set in $10.5 / 12$ pt Palatino by SPS

Printed in the UK by the Hobbs Printers 
For

Calum, Natasha and Lucienne and

Leon, Micol, Luce and Sofia 


\section{Acknowledgements}

WE ARE indebted to Daniele Girardi, Caetano Penna, Frank Brouwer and Jeff Masters for their invaluable editorial work on key chapters of this book.

We are very grateful to Joni Lovenduski and Deborah Mabbett at The Political Quarterly for their support, and for the great help provided by Emma Anderson. Thanks to Sandra Fardon Fox, Lena Hawkswood and Rachel Smith at Wiley Blackwell, and to Kristy Barker and Sarah Price for copy editing and proof reading.

Mariana Mazzucato acknowledges support from a research grant from the Institute for New Economic Thinking (grant no. 5474) and from the European Community's H2020-Euro-Society-2014 call on 'Overcoming the crisis: new ideas, strategies and governance structures for Europe' (ISIGrowth grant no. 649186). 


\section{Contents}

Notes on Contributors $\quad$ ix

1. Rethinking Capitalism: An Introduction

MICHAEL JACOBS and MARIANA MAZZUCATO 1

2. The Failure of Austerity: Rethinking Fiscal Policy

STEPHANIE KELTON

3. Understanding Money and Macroeconomic Policy

L. RANDALL WRAY and YEVA NERSISYAN

4. The Costs of Short-termism

ANDREW G. HALDANE

66

5. Innovative Enterprise and the Theory of the Firm WILLIAM LAZONICK

6. Innovation, the State and Patient Capital

MARIANA MAZZUCATO

7. Investment-led Growth: A Solution to the European Crisis

STEPHANY GRIFFITH-JONES and GIOVANNI COZZI

8. Inequality and Economic Growth

JOSEPH E. STIGLITZ

9. The Paradoxes of Privatisation and Public Service Outsourcing

COLIN CROUCH

156

10. Decarbonisation: Innovation and the Economics of Climate Change DIMITRI ZENGHELIS

11. Capitalism, Technology and a Green Global Golden Age: The Role of History in Helping to Shape the Future

CARLOTA PEREZ

Index

218 



\section{Notes on Contributors}

Michael Jacobs is Visiting Professor in the School of Public Policy and Department of Political Science at University College London. An environmental economist and political theorist, his work has focused on the political economy of environmental change. His books include The Green Economy: Environment, Sustainable Development and the Politics of the Future (Pluto Press, 1991), Greening the Millennium? The New Politics of the Environment (ed., Blackwell, 1997), The Politics of the Real World (Earthscan, 1996) and Paying for Progress: A New Politics of Tax for Public Spending (Fabian Society, 2000). From 2004 to 2010 he was a Special Adviser to the UK Prime Minister, responsible for domestic and international policy on energy and climate change, and before that (2004-2007) a member of the Council of Economic Advisers at the Treasury. He has previously been General Secretary of the Fabian Society, CoEditor of The Political Quarterly and a research fellow at Lancaster University and the London School of Economics.

Mariana Mazzucato is the RM Phillips Professor in the Economics of Innovation at SPRU at the University of Sussex. She has held academic positions at the University of Denver, London Business School, Open University and Bocconi University. Her book The Entrepreneurial State: Debunking Public vs. Private Sector Myths (Anthem, 2013) was on the Financial Times' 2013 Books of the Year list. She is winner of the 2014 New Statesman SPERI Prize in Political Economy and the 2015 Hans-Matthöfer-Preis, and in 2013 the New Republic called her one of the 'three most important thinkers about innovation'. She is an economic advisor to the Scottish government and the Labour Party, and is a member of the World Economic Forum's Global Agenda Council on the Economics of Innovation. Her current research is funded by the European Commission, the Institute for New Economic Thinking (INET), the Ford Foundation, NASA and the Brazilian Ministry for Science and Technology.

Stephanie Kelton is Professor of Economics at the University of Missouri-Kansas City. Her research expertise is in Federal Reserve operations, fiscal policy, social security, international finance and employment. She is best known for her contributions to the literature on Modern Monetary Theory. Her book, The State, The Market and the Euro (Edward Elgar, 2003) predicted the debt crisis in the eurozone. She served as Chief Economist on the US Senate Budget Committee and as an economic advisor to the Bernie Sanders 2016 presidential campaign. She was Founder and Editor-in-Chief of the top-ranked blog 'New Economic Perspectives' and a member of the TopWonks network of America's leading policy thinkers. She consults with policy-makers, investment banks and portfolio managers across the globe, and is a regular commentator on national radio and broadcast television.

L. Randall Wray is Professor of Economics at Bard College and Senior Scholar at the Levy Economics Institute. He is the author of Money and Credit in Capitalist Economies (Edward Elgar, 1990); Understanding Modern Money: The Key to Full Employment and Price Stability (Edward Elgar, 1998); and Modern Money Theory: A Primer on

(C) The Authors 2016. The Political Quarterly (C) The Political Quarterly Publishing Co. Ltd. 2016

Published by John Wiley \& Sons Ltd, 9600 Garsington Road, Oxford OX4 2DQ, UK and 350 Main Street, Malden, MA 02148, USA 
Macroeconomics for Sovereign Monetary Systems (Palgrave Macmillan, 2012, 2nd rev ed, 2015). He is also co-editor of, and a contributor to, Money, Financial Instability, and Stabilization Policy (Edward Elgar, 2006), and Keynes for the 21st Century: The Continuing Relevance of The General Theory (Palgrave Macmillan, 2008). His latest book is Why Minsky Matters: An Introduction to the Work of a Maverick Economist (Princeton University Press, 2016).

Yeva Nersisyan is Assistant Professor of Economics at Franklin and Marshall College. She received her BA in economics from Yerevan State University in Armenia in 2006, and her MA and PhD in economics and mathematics from the University of Missouri-Kansas City in 2013. She is a macroeconomist working in the postKeynesian and institutionalist traditions. Her research interests include banking and financial instability, and fiscal and monetary theory and policy. She has published a number of papers on shadow banking, fiscal policy, government deficits and debt, financial fragility and instability, financial reform and retirement policy.

Andrew G. Haldane is the Chief Economist at the Bank of England and Executive Director, Monetary Analysis and Statistics. He is a member of the Bank's Monetary Policy Committee. He also has responsibility for research and statistics across the Bank. In 2014, TIME magazine named him one of the 100 most influential people in the world. Andrew has written extensively on domestic and international monetary and financial policy issues. He is co-founder of 'Pro Bono Economics', a charity which brokers economists into charitable projects.

William Lazonick is Professor of Economics at University of Massachusetts Lowell. $\mathrm{He}$ is co-founder and president of the Academic-Industry Research Network. Previously, he was Assistant and Associate Professor of Economics at Harvard University, Professor of Economics at Barnard College of Columbia University and Distinguished Research Professor at INSEAD. His book Sustainable Prosperity in the New Economy? Business Organization and High-Tech Employment in the United States (Upjohn Institute, 2009) won the 2010 Schumpeter Prize. His article, 'Innovative Business Models and Varieties of Capitalism' received the Henrietta Larson Award from Harvard Business School for best article in Business History Review in 2010. His article 'Profits Without Prosperity: Stock Buybacks Manipulate the Market and Leave Most Americans Worse Off' was awarded the HBR McKinsey Award for outstanding article in Harvard Business Review in 2014. He is currently completing a book, The Theory of Innovative Enterprise, to be published by Oxford University Press.

Stephany Griffith-Jones is Financial Markets Director, Initiative Policy Dialogue, Columbia University; Emeritus Professor, Institute of Development Studies, Sussex University, where she was Professorial Fellow; and Research Associate, Overseas Development Institute. An economist, she has led many major international research projects on international and domestic financial issues and has published widely, having written or edited over twenty books and numerous journal and newspaper articles. Her books include Time for a Visible Hand: Lessons from the 2008 World Financial Crisis, co-edited with Jose Antonio Ocampo and Joseph Stiglitz (Oxford University Press, 2010), and Achieving Financial Stability and Growth in Africa, coedited with Ricardo Gottschalk (Routledge, 2016). She has advised many international organisations, including the European Commission, European Parliament, World Bank, Commonwealth Secretariat, IADB and various UN agencies 
and several governments and central banks, including those of the UK, Chile, Sweden, South Africa, Tanzania, Brazil and Czech Republic.

Giovanni Cozzi is Senior Lecturer in Economics at the University of Greenwich and a member of the Greenwich Political Economy Research Centre. He was formerly Senior Economist at the Foundation for European Progressive Studies (FEPS) in Brussels and Research Fellow at the Centre for Development Policy and Research at the School of Oriental and African Studies. His current research is on fiscal policies, the role of social and physical investment in promoting sustainable growth and employment and the role of development banks. Several of his research publications employ the Cambridge Alphametrics Model (CAM), a structuralist growth model, to project alternative macroeconomic scenarios and their policy implications.

Joseph E. Stiglitz is University Professor at Columbia University, the winner of the 2001 Nobel Prize in Economics and the John Bates Clark Medal. He was also one of the lead authors of the 1995 report of the Intergovernmental Panel on Climate Change, which shared the 2007 Nobel Peace Prize. He is Co-Chair of the High-Level Expert Group on the Measurement of Economic Performance and Social Progress at the OECD, Chief Economist of the Roosevelt Institute, and the Founder and CoPresident of Columbia University's Initiative for Policy Dialogue. He was Chairman of the US Council of Economic Advisors under President Clinton and Chief Economist and Senior Vice President of the World Bank from 1997 to 2000. He held the Drummond Professorship at All Souls College Oxford and has taught at MIT, Yale, Stanford and Princeton. His books include Globalization and its Discontents (Penguin, 2002), The Price of Inequality (Penguin, 2012) and The Great Divide: Unequal Societies and What We Can Do About Them (Allen Lane, 2015).

Colin Crouch is a Professor Emeritus of the University of Warwick and external scientific member of the Max Planck Institute for the Study of Societies at Cologne. He is vice-president for social sciences of the British Academy. He is a former editor and former chair of the editorial board of The Political Quarterly. He has published within the fields of comparative European sociology and industrial relations, economic sociology and contemporary issues in British and European politics. His most recent books include Post-Democracy (Polity, 2004); Capitalist Diversity and Change: Recombinant Governance and Institutional Entrepreneurs (Oxford University Press, 2005); The Strange Non-death of Neoliberalism (Polity, 2011); Making Capitalism Fit for Society (Polity, 2013); Governing Social Risks in Post-Crisis Europe (Edward Elgar, 2015); The Knowledge Corrupters: Hidden Consequences of the Financial Takeover of Public Life (Polity, 2015); and Society and Social Change in 21st Century Europe (Palgrave Macmillan, 2016).

Dimitri Zenghelis is Co-Head, Climate Policy at the Grantham Research Institute on Climate Change and the Environment at the London School of Economics. In 20132014 he was Acting Chief Economist for the Global Commission on the Economy and Climate. He was recently Senior Economic Advisor to Cisco's long-term innovation group (2008-2013) and an Associate Fellow at the Royal Institute of International Affairs, Chatham House. Previously, he headed the Stern Review Team at the Office of Climate Change, London, and was a senior economist on the Stern Review on the Economics of Climate Change, commissioned by the then Chancellor Gordon Brown. Before working on climate change, he was Head of Economic Forecasting at HM Treasury. He has also worked at Oxford Economics, the Institute of International Finance, Washington DC, and Tokai Bank Europe, London. 
Carlota Perez is Centennial Professor of International Development at the London School of Economics, Professor of Technology and Development at TUT, Estonia, and Honorary Professor at SPRU, University of Sussex. She is the author of Technological Revolutions and Financial Capital: the Dynamics of Bubbles and Golden Ages (Edward Elgar, 2002). She conducts interdisciplinary research on the changing impact of technical change on world development. She has always combined teaching and research with consultancy and civil service. As Director of Technological Development in the Ministry of Industry of Venezuela, she created the nation's first venture capital fund. As a consultant she has worked for business (including IBM, Cisco and PDVSA), several governments and various multilateral organisations (such as IADB, UNCTAD, CEPAL, OECD, the World Bank and the EU). Her current research project, on the role of the state in shaping the context for innovation, is being funded by the Anthemis Institute. 


\section{Rethinking Capitalism: An Introduction}

MICHAEL JACOBS AND MARIANA MAZZUCATO

IN NOVEMBer 2008, as the global financial crash was gathering pace, the 82-year-old British monarch Queen Elizabeth visited the London School of Economics. She was there to open a new building, but she was more interested in the assembled academics. She asked them an innocent but pointed question. Given its extraordinary scale, how was it possible that no one saw the crash coming? ${ }^{1}$

Hereditary sovereigns are not normally given to puncturing the pretensions of those in charge of the global economy, or of the economists paid to understand it. But the Queen's question went to the heart of two huge failures. Western capitalism came close to collapsing in 2007-2008, and has still not recovered. And the vast majority of economists had not understood what was happening. ${ }^{2}$

This book is about both failures. On the one hand the capitalist economies of the developed world, which for two hundred years transformed human society through an unparalleled dynamism, have over the past decade looked profoundly dysfunctional. Not only did the financial crash lead to the deepest and longest recession in modern history; nearly a decade later, few advanced economies have returned to anything like a normal or stable condition, and growth prospects remain deeply uncertain. Even during the pre-crash period when economic growth was strong, living standards for the majority of households in developed countries barely rose. Inequality between the richest groups and the rest of society has now grown to levels not seen since the nineteenth century. Meanwhile continued environmental pressures, especially those of climate change, have raised profound risks for global prosperity.

At the same time, the discipline of economics has had to face serious questions about its understanding of how modern economies work. What made the financial crisis such a shock - in two senses - was not simply that very few economists had predicted its coming. It was that over the previous decade the mainstream view was that policy-making had essentially solved the fundamental problem of the business cycle: major depressions, it was believed, should now be a thing of the past. And economic policy since the crisis has been no more successful. The orthodox prescription of 'fiscal austerity' - cutting public spending in an attempt to reduce public deficits and debt-has not restored Western economies to health, and economic policy has signally failed to deal with the deep-lying and long-term weaknesses which beset them.

The core thesis of this book is that these failures in theory and policy are related. Mainstream economic thinking has given us inadequate resources to

(C) The Authors 2016. The Political Quarterly (C) The Political Quarterly Publishing Co. Ltd. 2016

Published by John Wiley \& Sons Ltd, 9600 Garsington Road, Oxford OX4 2DQ, UK and 350 Main Street, Malden, MA 02148, USA 
understand the multiple crises which contemporary economies now face. To address these crises, we need a much better understanding of how modern capitalism works - and why in key ways it now doesn't. A reappraisal of some of the dominant ideas in economic thought is required. And in turn this needs to inform a set of new directions in economic policy-making which can more successfully tackle modern capitalism's problems.

Each of the chapters of the book therefore addresses both a key economic problem and the orthodox economic way of understanding it. The authors offer a different and more sophisticated approach to economic analysis, and from this generate new policy solutions. To do this they draw on important schools of economic thought whose powerful understandings of capitalist systems have been largely forgotten or sidelined in mainstream debate. In each case their conclusion is that capitalism can be reshaped and redirected to escape its present failures. But this can only be achieved if the mental frameworks of economics are rethought, and new approaches to policy taken.

\section{Capitalism and its discontents}

In this Introduction we pull together some of the key ideas which animate the book. We first set out the evidence of Western capitalism's failures, explaining the three fundamental problems which define its current weak performance. After describing the approach taken to these problems by each chapter, we draw out some of the lessons for economic theory and analysis. We offer a critique of the orthodox notions of markets and 'market failure'. And we explain how a richer and deeper understanding of capitalism can generate more successful approaches to economic policy, aimed at achieving more innovative, inclusive and sustainable forms of growth and prosperity.

\section{Weak and unstable growth}

There is no escaping the starting point for this analysis. The financial crash of 2008, and the long recession and slow recovery which followed, have provided the most obvious evidence that Western capitalism is no longer generating strong or stable growth.

The scale of the crash can hardly be exaggerated. In 2009 real gross domestic product fell in thirty-four of thirty-seven advanced economies and the global economy as a whole went into recession for the first time since World War II. ${ }^{3}$ In a single year, real GDP fell by 4.5 per cent across the euro zone (including by 5.6 per cent in Europe's strongest economy, Germany), 5.5 per cent in Japan, 4.3 per cent in the UK and 2.8 per cent in the United States. ${ }^{4}$ Between 2007 and 2009, global unemployment rose by around 30 million, over half of which was in advanced economies, including an increase of 7.5 million people in the US. ${ }^{5}$ 
To prevent an even bigger crisis, governments were forced to put unprecedented sums of taxpayers' money into bailing out the banks whose lending practices had precipitated the crisis. In the US the Federal Reserve had at its peak $\$ 1.2$ trillion of emergency loans outstanding to thirty banks and other companies. In the UK, the government's exposure for support provided to the banks in the form of cash and guarantees peaked at $£ 1.162$ trillion. ${ }^{6}$ At the same time governments undertook major stimulus measures to try to sustain demand as private spending and investment collapsed. The huge drop in output and the rise in unemployment led to large increases in public deficits as tax revenues fell and the 'automatic stabilisers' of welfare payments and other public spending took effect. In 2009-2010 these deficits reached as much as 32.3 per cent in Ireland, 15.2 per cent of GDP in Greece, 12.7 per cent in the US, 10.8 per cent in the UK, 8.8 per cent in Japan and 7.2 per cent in France. ${ }^{7}$

The financial crash exposed fundamental weaknesses in the functioning and regulation of the global financial system. As former Chairman of the Federal Reserve Alan Greenspan grudgingly acknowledged in his testimony to Congress, there had been a 'flaw' in the theory underpinning the Western world's approach to financial regulation. The presumption that 'the selfinterest of organisations, specifically banks, is such that they were best capable of protecting shareholders and equity in the firms' had proved incorrect. ${ }^{8}$ Contrary to the claims of the 'efficient markets hypothesis' which underpinned that assumption, financial markets had systematically mispriced assets and risks, with catastrophic results. ${ }^{9}$

The financial crash of 2008 was the most severe since that of 1929. But as Carmen Reinhart and Kenneth Rogoff have pointed out, since most countries undertook financial liberalisation in the 1970s and 1980s, there has been a marked increase in the frequency of banking crises (see Figure 1). ${ }^{10}$ Globally, in the period 1970 to 2007, the International Monetary Fund has recorded 124 systemic bank crises, 208 currency crises and 63 sovereign debt crises. ${ }^{11}$ For modern capitalism instability has become, not the exception, but a seemingly structural feature.

Unsurprisingly, policy-makers have focused since the crash on improving the regulation of banks and seeking to increase the overall stability of the financial system. ${ }^{12}$ But important though this is, it does not address the more fundamental failure of modern capitalist economies to generate enough public and private investment in the real economy to fuel growth and a sustained level of demand.

The financial crisis exposed the uncomfortable truth that much of the apparently benign growth which had occurred in the previous decade did not in fact represent a sustainable expansion of productive capacity and national income. Rather, it reflected an unprecedented increase in household and corporate debt (see Figure 2). Low interest rates and lax lending practices, particularly for land and property, had fuelled an asset price bubble which would inevitably burst. In this sense the pre-crisis growth of output can be judged only alongside its post-crisis collapse. 


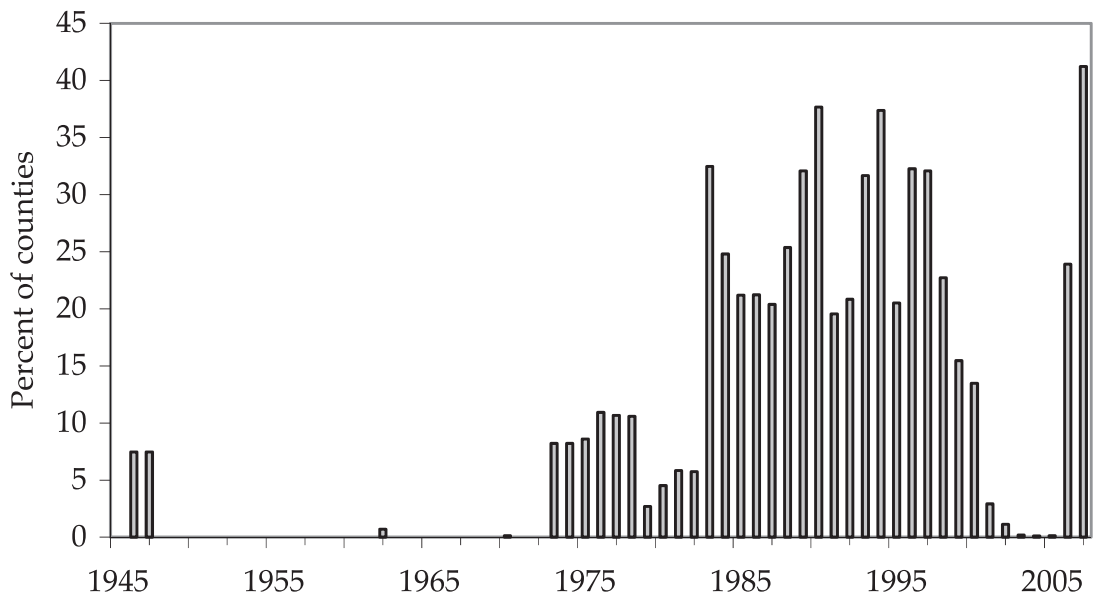

Figure 1: Percentage of countries experiencing a banking crisis (1945-2008) (weighted by their share of world income)

Note: Sample size includes all countries that were independent states in the given year.

Source: C. M. Reinhart and K. S. Rogoff, This Time is Different: Eight Centuries of Financial Folly, Princeton, NJ, Princeton University Press, 2009.

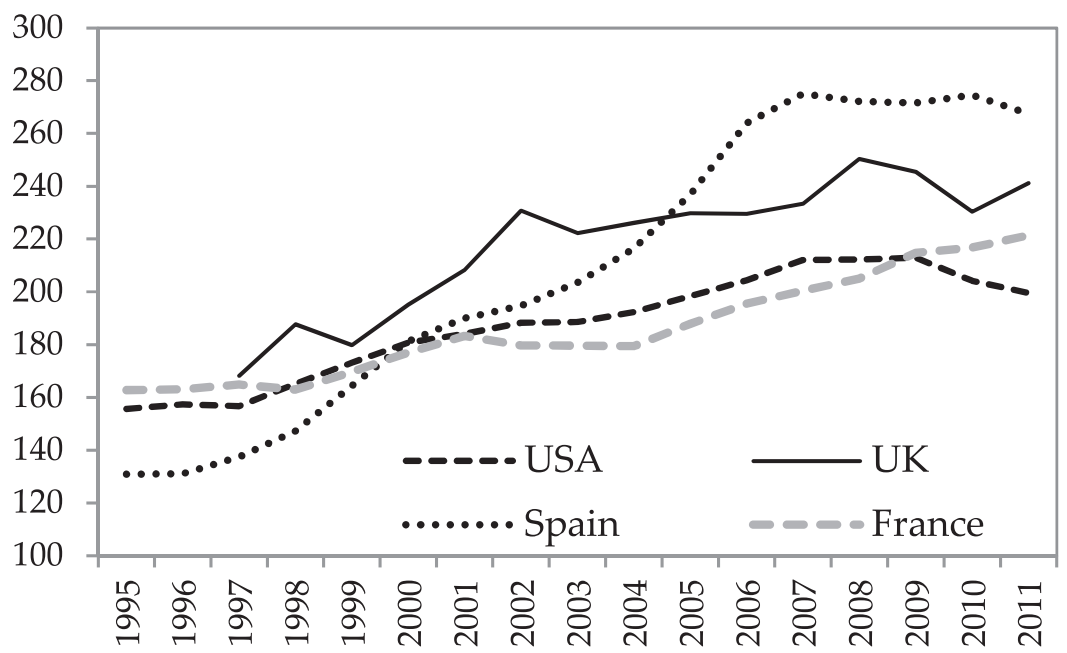

Figure 2: Outstanding private debt (\% of GDP)

Source: OECD.stat (http://stats.oecd.org/index.aspx?queryid=34814 (accessed 12 April 2016)).

Since 2008, most Western economies have gradually returned to economic growth. But the recovery was the slowest in modern times. Output in the US, France and Germany did not return to pre-crash levels for fully three 


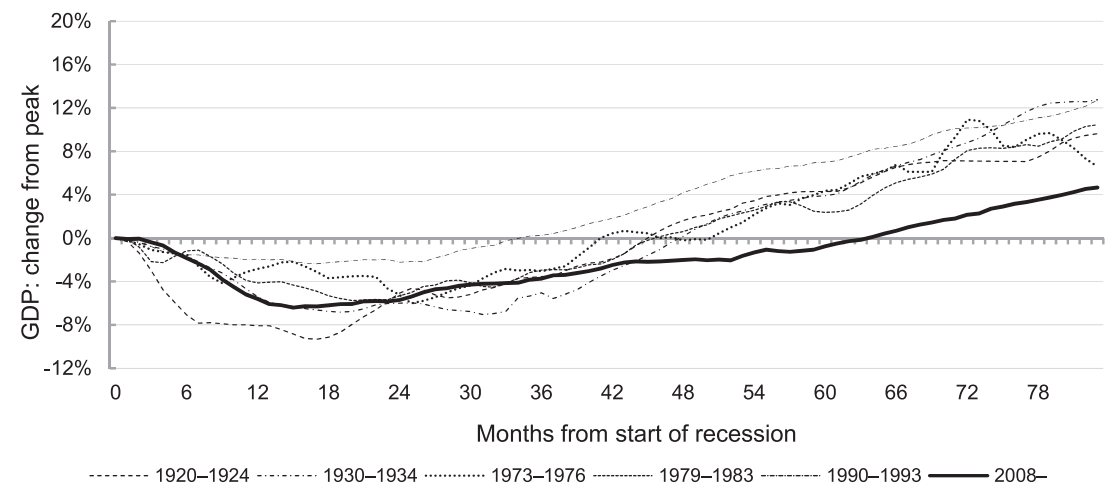

Figure 3: Comparing profiles of UK recessions and recoveries

Notes: Calculated from centred three-month moving averages of monthly GDP; the effect of the miners' strike in 1921 is excluded from the 1920-4 profile (the strike started on 31 March 1921 and ended on 28 June 1921). The effects of the miners' strike and the General Strike in 1926 are also excluded.

Source: National Institute of Economic and Social Research, NIESR Monthly Estimates of GDP, $7^{\text {th }}$ October, 2014, London, 2014, p. 1, http://www.niesr.ac.uk/sites/default/files/publications/gdp1014.pdf (accessed 12 April 2016).

years. For the UK it took more than five (see Figure 3). Across most developed economies, unemployment has remained stubbornly above its pre-crisis rate. It was higher in 2014 than in 2007 in twenty-eight of thirty-three OECD countries for which comparable data is available (see Figure 4). ${ }^{13}$ Even in countries where unemployment is lower than in 2007 or has been falling since its post-crisis peak, wages have been largely stagnant in real terms (see Figure 5). In the UK, where employment has grown, real wages suffered their sharpest decline since records began in $1964 .{ }^{14}$

Underpinning this weak growth pattern has been a dramatic collapse in private sector investment. Investment as a proportion of GDP had already been falling throughout the previous period of growth (see Figure 6). Since 2008 this has occurred despite the unprecedented persistence of near-zero real interest rates, bolstered in most of the major developed economies by successive rounds of 'quantitative easing', through which central banks have sought to increase the money supply and stimulate demand. Yet they have barely succeeded, as continuing low inflation rates have revealed.

The decline in investment is also related to the marked 'financialisation' of the corporate sector. Over the past decade or so, an increasing percentage of corporate profits has been used for share buybacks and dividend payments rather than for reinvestment in productive capacity and innovation. Between 2004 and 2013 share buybacks by Fortune 500 companies amounted to a remarkable $\$ 3.4$ trillion. In 2014, these companies returned $\$ 885$ billion to shareholders, more than their total net income of $\$ 847$ billion. ${ }^{15}$ 


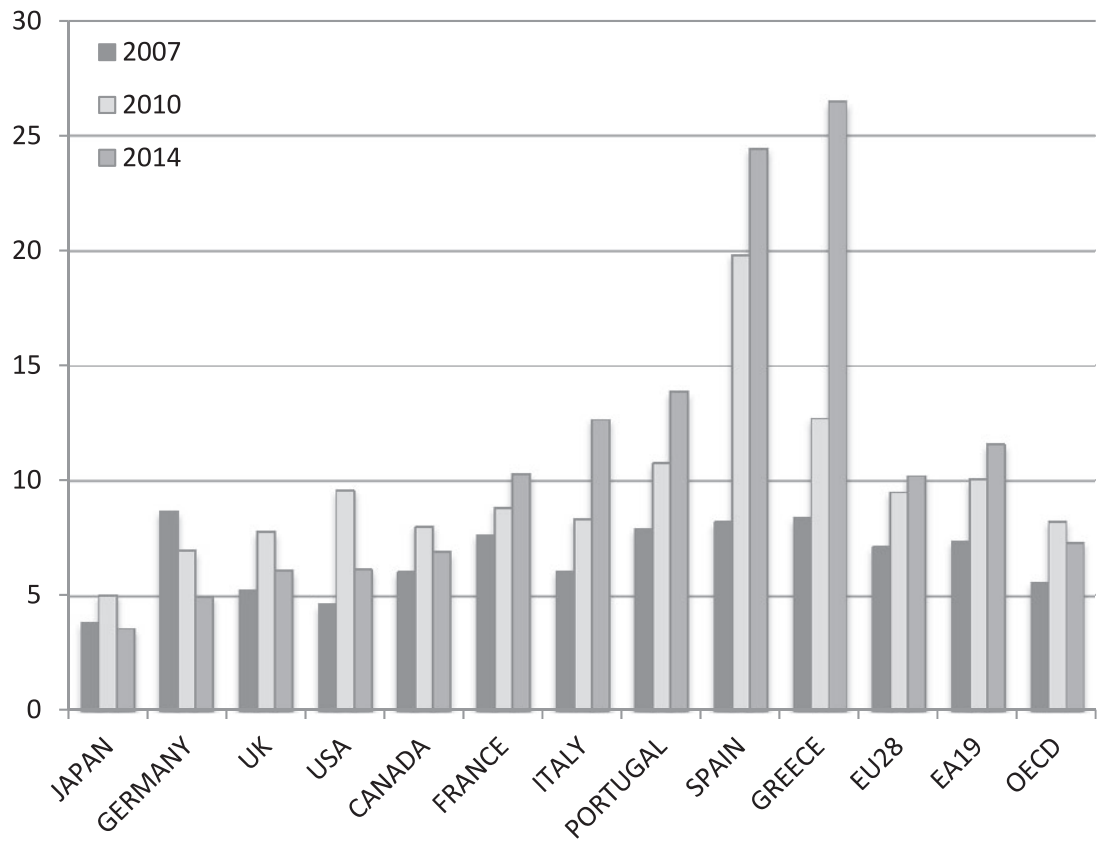

Figure 4: Unemployment rates, selected countries, 2007, 2010 and 2014 Source: OECD.stat (https://data.oecd.org/unemp/unemployment-rate.htm (accessed 12 April 2016)).

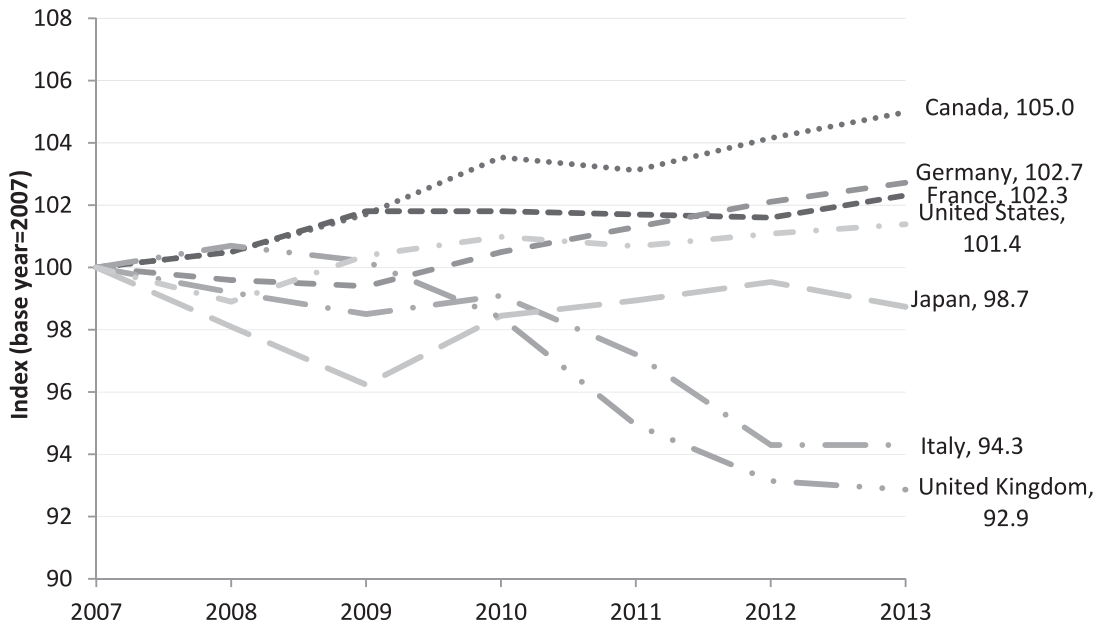

Figure 5: Average real wage index for selected developed countries, 2007-2013 Source: ILO Global Wage Report 2014/15, Geneva, International Labour Office, Geneva, 2015. 


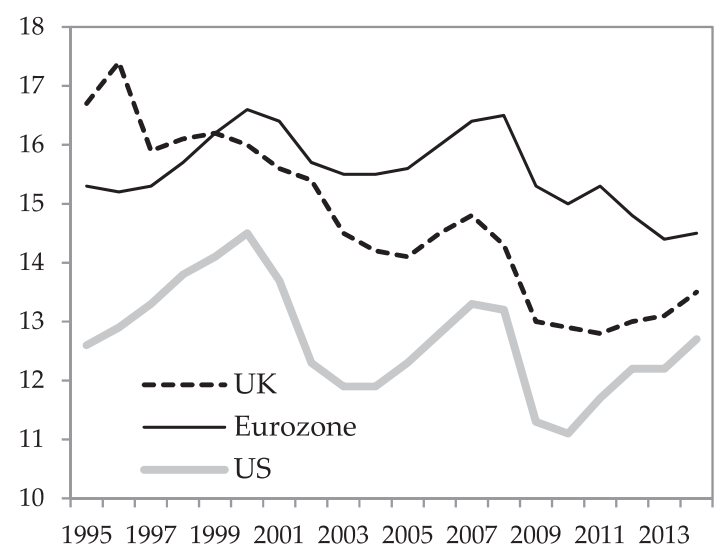

Figure 6: Investment (gross non-residential fixed capital formation) as a percentage of GDP

Source: Eurostat (http://ec.europa.eu/eurostat/data/database (accessed 12 April 2016)).

One critical result of the decline in investment is that productivity growth has also been weak relative to historic trends. In the decade prior to the crisis, labour productivity growth was below trend in almost all G7 countries, in some continuing a thirty-year decline. Since the financial crisis it has fallen further in most developed countries, including the US, Japan, France and the UK. ${ }^{16}$ At the same time there appears to be some evidence that rates of productivity-enhancing innovation have also slowed down. ${ }^{17}$ All this has led some economists to ask whether Western capitalism has entered a period of 'secular stagnation', in which a structural weakness of investment and demand leaves positive interest rates no longer able to support full employment. While such a prospect should not be regarded as somehow inevitable, it reflects a widespread concern that developed economies may face a long period of low growth and financial instability. ${ }^{18}$

\section{Stagnant living standards and rising inequality}

But weak and unstable growth is only part of modern capitalism's problem. One of the most striking features of Western economies over the past four decades is that, even when growth has been strong, the majority of households have not seen commensurate increases in their real incomes. In the US, real median household income was barely higher in 2014 than it had been in 1990, though GDP had increased by 78 per cent over the same period. ${ }^{19}$ Though beginning earlier in the US, this divergence of average incomes from overall economic growth has now become a feature of most advanced economies.

There are in fact three separate trends here. In most developed countries, the total share of labour (salaries and wages) in overall output has fallen, 
earnings have not kept pace with gains in productivity and the distribution of the reduced labour share has become more unequal.

Across advanced economies, the share of GDP going to labour fell by 9 per cent on average between 1980 and 2007, including 5 per cent in the US (from 70 to 65 per cent), 10 per cent in Germany (from 72 to 62 per cent) and fully 15 per cent in Japan (from 77 to 62 per cent). ${ }^{20}$ Pay tended to track productivity until the 1970s. But since 1980, real hourly labour productivity in the US (non-farm) business sector has increased by around 85 per cent, while real hourly compensation has increased by only around 35 per cent. $^{21}$ Since 1999, the ILO calculates that across thirty-six developed economies, labour productivity has increased at almost three times the rate of real wage growth (see Figure 7).

At the same time as the labour share has been falling, more of it has been going to workers at the top of the earnings scale and less to those in the middle and bottom. Across advanced economies, higher-skilled workers claimed an additional 6.5 percentage points of the labour share between 1980 and 2001, whereas low-skilled workers saw their portion shrink by 4.8 percentage points. ${ }^{22}$

Meanwhile, those at the very top of the income distribution have done exceedingly well. In the US, between 1975 and 2012, the top 1 per cent gained around 47 per cent of the entire total of pre-tax increase in incomes (see Figure 8). In Canada over the same period it was 37 per cent, and in

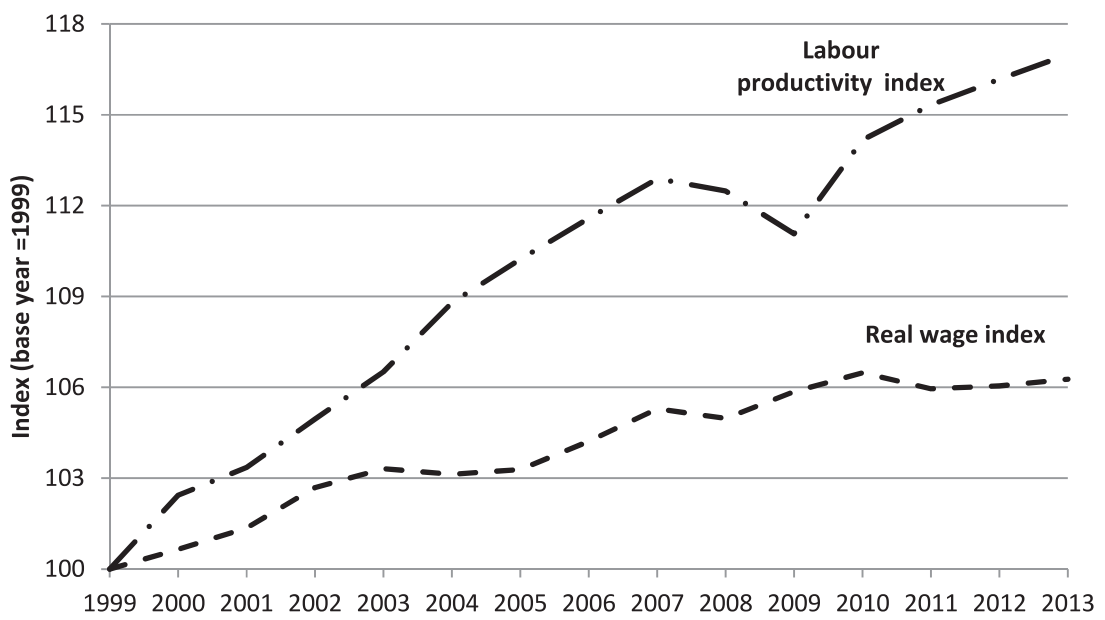

Figure 7: Trends in growth in average wages and labour productivity in thirty-six developed economies, 1999-2013

Note: Wage growth is calculated as a weighted average of year-on-year growth in average monthly real wages in thirty-six developed economies. Index is based on 1999 because of data availability.

Source: ILO Global Wage Report 2014/15, Geneva, International Labour Office, 2015. 
Australia and the UK over 20 per cent. ${ }^{23}$ In the US, the incomes of the richest 1 per cent rose by 142 per cent between 1980 and 2013 (from an average of $\$ 461,910$, adjusted for inflation, to $\$ 1,119,315$ ) and their share of national income doubled, from 10 to 20 per cent. In the first three years of the recovery after the 2008 crash, an extraordinary 91 per cent of the gains in income went to the richest one-hundredth of the population. ${ }^{24}$ Overall, across the OECD over the past twenty years, the proportion of the labour share taken by the top 1 per cent of earners has increased by a fifth. ${ }^{25}$

At the same time, most developed countries have seen labour markets become more polarised and insecure. In the decade between the late 1990s and late 2000s, the proportion of low-paid workers increased in most advanced economies. ${ }^{26}$ Since the financial crash unemployment has remained stubbornly high, particularly among young people. Across the OECD, unemployment in the 16-25 age group averaged 15 per cent in 2014, with rates of over a third in Spain, Portugal, Italy and Greece. ${ }^{27}$ 'Nonstandard' work (covering part-time, temporary and self-employed work, though not all of this is insecure) now accounts for around a third of total employment in the OECD, including half the jobs created since the 1990s and 60 per cent since the 2008 crisis. In 2013 almost three in ten part-time workers across the OECD were 'involuntary', meaning that they wanted to work full-time but could only find part-time jobs. ${ }^{28}$

The result of these trends has been a rise in inequality across the developed world. Between 1985 and 2013, the Gini coefficient measuring income inequality increased in seventeen OECD countries, was little changed in four and decreased in only one (Turkey). ${ }^{29}$ Wealth inequality has grown even more than that of income, a result both of the shift in the distribution of earnings away from wages and towards profits and of the huge increase in land and property values. In the UK the share of national wealth owned by the top 1 per cent rose from 23 per cent in 1970 to 28 per cent in 2010. In the

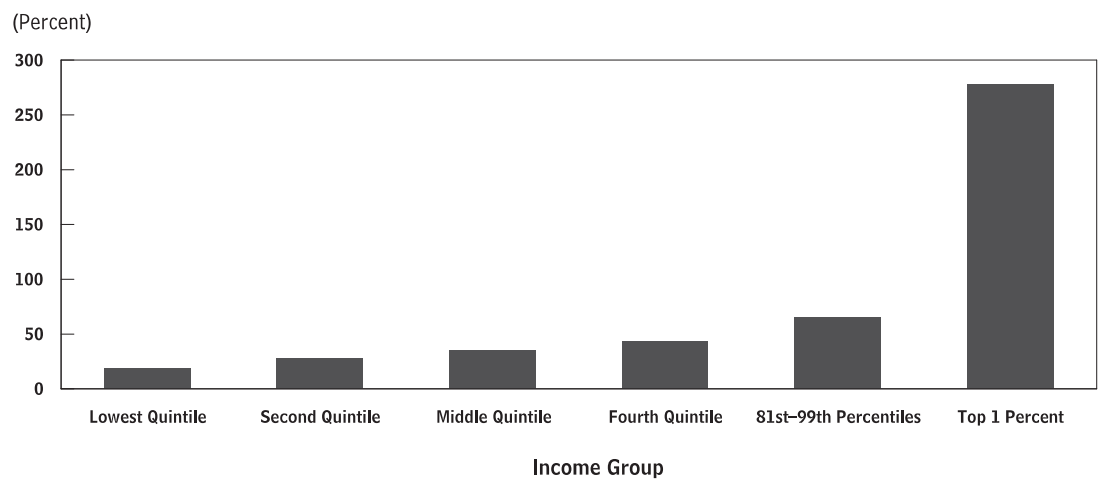

Figure 8: Growth in real after-tax income from 1979 to 2007, US Source: Congressional Budget Office, Trends in the Distribution of Household Income Between 1979 and 2007, Congressional Budget Office Publication No. 4031, 2011, Summary Figure 1. 
US it has risen from 28 to 34 per cent over the same period. In the US in 2010, the top 0.1 per cent alone owned almost 15 per cent of all wealth. In both countries, over 70 per cent of all wealth is now owned by a tenth of the population. ${ }^{30}$

\section{Climate change and environmental risk}

Underlying these recent trends in modern capitalism is another, deeper one. This is that of rising global greenhouse gas emissions, which have put the world at severe risk of catastrophic climate change.

Throughout capitalism's history economic growth has been accompanied by environmental damage, from the pollution of air, water and land to the loss of habitats and species, a constant subtraction from its successes in increasing welfare. In developed countries some of these problems have been partially tackled; but none has been solved. It remains too little acknowledged how dependent human societies are on the biophysical processes which underpin them, and how dangerous are the critical thresholds (or 'planetary boundaries') which many of these processes have now reached or are close to reaching. ${ }^{31}$

But climate change poses a unique kind of global threat. The cumulative effect of two hundred years of fossil fuel use in the developed world, now compounded by rapid growth in the emerging economies, means that, unless current emissions levels are drastically reduced, the world faces serious damage. At current emissions rates, the earth is on course for an increase in average global temperature of 3-4 degrees Celsius or more. Even above 2 degrees of warming, the Intergovernmental Panel on Climate Change warns that we can expect a much higher incidence of extreme weather events (such as flooding, storm surges and droughts), which may lead to a breakdown of infrastructure networks and critical services, particularly in coastal regions and cities; lower agricultural productivity, increasing the risk of food insecurity and the breakdown of food systems; increased ill-health and mortality from extreme heat events and diseases; greater risks of displacement of peoples and conflict; and faster loss of ecosystems and species. ${ }^{32}$

Broadly speaking, the evidence on this has been known for a quarter of a century. ${ }^{33}$ But until very recently very little has been done to avoid it. The major reason is that the production of greenhouse gas emissions-particularly carbon dioxide - is so embedded in capitalism's historic systems of production and consumption, which have been built on the use of fossil fuels. In total 80 per cent of the world's energy still comes from oil, gas and coal. In developed economies, as a result both of structural deindustrialisation and recent climaterelated policies, emissions are now declining. But part of this is simply due to the effective transfer of production to the developing world as globalisation has occurred. ${ }^{34}$ Western economies are not yet reducing their emissionseither those they generate themselves or those embodied in the goods and services they import-at anything like the speed required to control global 
warming (see Figure 9). Modern capitalism has in effect been storing up profound risks to its own future prosperity and security.

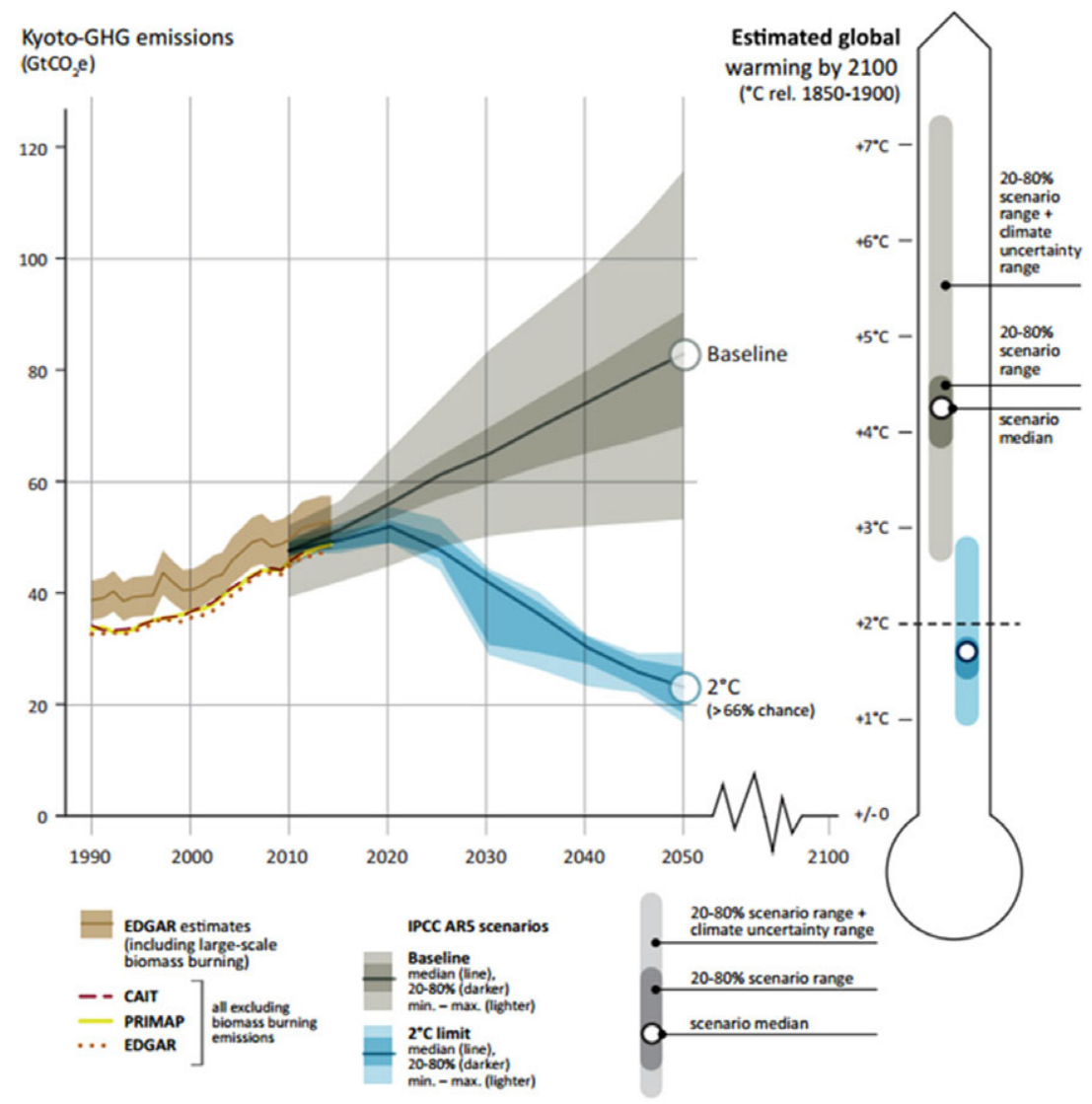

Figure 9: Global greenhouse gas emissions 1990-2050

Source: UNEP, The Emissions Gap Report 2015, Nairobi, United Nations Environment Programme, 2015, based on scenarios in the Intergovernmental Panel on Climate Change 5th Assessment Report, 2014, http://uneplive.unep.org/media/docs/theme/13/EGR_2015_301115_lores.pdf (accessed 12 April 2016).

\section{Rethinking economic policy}

In all these ways, therefore, the performance of Western capitalism in recent decades has been deeply problematic. The problem is that these failings are not temporary; they are structural. Regulators are now seeking to reduce the systemic risks created by financial market behaviour; but the complexity of the modern financial system has generated widespread concern that they cannot be eliminated. Strongly embedded incentives for both asset-holders and senior corporation executives create powerful tendencies towards 
short-termism in both finance and industry. Low levels of investment, particularly in innovation, arise both from these incentives and from entrenched weaknesses in demand across the world's economies. Stagnant real wages and rising inequality spring from the structures of the labour market, corporate remuneration and ownership of land and wealth. High greenhouse gas emissions are embedded in the structures of energy and transport systems. None of these problems look likely to be solved by current approaches to economic policy in any developed country.

This does not mean, however, that there are no solutions. Western capitalism is not irretrievably bound to fail; but it does need to be rethought. For as the authors collected together in this book argue, the orthodox economic theory which underpins most current policy-making does not provide a proper understanding of how modern capitalism works, and therefore how to make it work better. They therefore base their prescriptions for new policies on a critique of the dominant approach to economics in their field and the presentation of a more powerfully explanatory alternative. Each chapter addresses a particular problem of modern capitalism and the associated policy debate.

One of the most contentious of those debates has concerned the role of fiscal and monetary policy in response to the financial crisis and the ensuing slow recovery. In their chapters, Stephanie Kelton, and Randall Wray and Yeva Nersisyan take issue with the orthodox prescription of fiscal austerity. Kelton's argument is that austerity is based on a fundamental economic misunderstanding. The claim that high deficits caused the recession turns the facts on their head: it was the recession which caused deficits to balloon, as the downturn slashed the tax revenues earned by governments and the automatic stabilisers of social security benefits and public spending went into operation. Kelton shows that in fact the deficits prevented the recession becoming much worse, generating demand just as the dramatic reduction in private consumption and investment was cutting it. Since all saving and borrowing in an economy (including its overseas sector) must by definition balance, increased public debt was an inevitable consequence of the huge retrenchment of private saving which occurred after the crash. By withdrawing demand from the economy in an attempt to get deficits down as quickly as possible, austerity policies have delayed recovery and, in the case of particularly hard-hit countries such as Greece, Spain and Portugal, largely prevented it. Very slow growth meant that deficits did not, in fact, fall as quickly as anticipated: austerity did not succeed even in its own objective.

Wray and Nersisyan go further. They argue that the orthodox view of macroeconomic policy stems from an incorrect understanding of the nature of money. Rather than being exogenously determined by the central authorities, as the orthodox view has it, money is effectively created whenever commercial banks lend, and thereby increase their borrowers' purchasing power. Money is endogenous to the real economy. Examining the operations of modern central banks, Wray and Nersisyan show that for a nation with its 
own currency, government spending is not constrained by the resources available from taxation or borrowing. ${ }^{35}$ The euro zone in particular has suffered from its rules expressly designed to prevent weaker European economies from borrowing in the absence of their own currency. Quantitative easing meanwhile is a poor way of boosting aggregate demand. Fiscal policy, the authors argue, is a much more powerful and effective tool for stimulating growth.

Perhaps unsurprisingly, austerity policies have not succeeded in reversing the low levels of investment which have characterised Western economies for a long period. In their chapters, Andrew Haldane, William Lazonick, Mariana Mazzucato, and Stephany Griffith-Jones and Giovanni Cozzi address the economic sources of this problem.

Haldane asks if short-termism in financial markets may have reduced the willingness of firms to invest. Examining how far share prices reveal excessive discounting of future earnings, he finds an economically significant effect in the period since 1995 that was absent in the previous decade. Similarly, analysing the comparative behaviour of private and publicly quoted firms in distributing dividends, rather than retaining earnings for investment, he finds that UK private firms tend to plough between four and eight times more of their profits back into their business over time than publicly held firms. Overall, he concludes that short-termism appears to be making a material difference to corporate investment behaviour. He suggests various policy remedies, including greater transparency of long-term business strategy, changes in the ways senior executives are remunerated, reforms to shareholder governance and changes in the taxation regime to reward long-term asset holding.

Lazonick focuses on the orthodox economic theory of the firm. Neoclassical economists draw on a model of the firm as an optimising profit-maker constrained in its behaviour by the competitive markets in which it operates. But such a model cannot explain the phenomenon of innovation. Offering an alternative theory of the innovative enterprise-firms which generate improvements in productivity and more competitive goods and services, and are therefore the wellsprings of economic growth-Lazonick argues that the key is not the nature of the market, but the structure and organisation of the firm. Using the comparative example of Japanese and American industrial businesses in the second half of the twentieth century, he shows how different organisational and management methods generate different degrees of innovation, and therefore commercial success. He argues that only by studying real historical examples, rather than merely abstract theory, can economists properly understand how innovation and economic development occur.

Mazzucato's chapter picks up this theme. The orthodox economic view is that innovation is carried out by the private sector, and government policy should be restricted to basic scientific research. But Mazzucato shows that this is a misconception; in fact the modern state, particularly in the US, has 
been a driver of innovation in a whole range of fields. All the new technologies in the Apple iPhone, for example, were developed with government support. Detailing how reluctant private investors have become to finance innovation - contrary to the orthodox myth of 'venture capitalism' - she argues for an 'entrepreneurial state' investing in innovation to address major societal problems such as climate change and elderly healthcare. Given the risks that 'directing' innovation entails (choosing particular missions, technologies, sectors and firms to support), taxpayers should share in the rewards. She argues that state investment banks, such as Germany's KfW, can play a particularly important role in directing long-term 'patient' capital to higher-risk infrastructure and innovation.

Griffith-Jones and Cozzi then show what an investment programme based on these principles might achieve. Criticising the inadequate response of European Union policy-makers to the slow recovery after the financial crash, the authors propose a five-year investment stimulus package based on additional lending by the European Investment Bank (the EU's state investment bank). Taking issue with the orthodox economic view that public investment will ultimately 'crowd out' private, they argue that at very low interest rates, with a glut of capital looking for returns, the opposite is in fact the case: public investment will leverage greater private capital. They use a macroeconomic model to compare their investment package to 'business as usual': they find that not only would it increase European growth rates and employment, it would also reduce public deficits more rapidly.

The chapters by Joseph Stiglitz and Colin Crouch look at two of the major gaps between orthodox economic theory and the reality of modern capitalism. Stiglitz addresses the growth of inequality over the past thirty years. He takes on the neoclassical view that wages and salaries reflect the marginal productivity of workers, showing that the very high incomes of corporate executives in fact reveal a form of 'rent-seeking', in which rewards are extracted without relation to productivity or economic desert. Moreover he points out-again contrary to the orthodox view-that such inequality is not the price that has to be paid for greater economic prosperity, but actually retards growth. Stiglitz offers a range of policy measures which would reverse recent trends, including changes to executive compensation schemes, macroeconomic policies to reduce unemployment, greater investment in education and the reform of capital taxation. He concludes by insisting that economic policy indicators must do more than measure growth of GDP: its distribution and content also matter.

Crouch looks at the experience of privatisation and outsourcing. Over recent decades, a number of countries (notably the UK) have privatised nationalised industries and outsourced public services to market competition. These policies have followed the precepts of neoliberal economic theory, which argues that competition in markets will generate greater efficiency and consumer choice. But Crouch notes that this is not in fact what has happened. In practice, in both privatised industries and public service provision, 
oligopolies have been created, resulting in very little competition or consumer choice. What were intended to be market-based processes have become deeply politicised, a form of 'corporate neoliberalism' which runs contrary to the theory's original claims. He argues that corporate lobbying has now become so powerful that the principles of democracy itself are threatened.

The final two chapters of the book examine capitalism's environmental consequences. Dimitri Zenghelis shows why climate change poses such a challenge, not just to the economic system, but also to economics. The science of climate change means that greenhouse gas emissions must ultimately be reduced to near zero if the rise in global temperature is to be stopped. But almost all economic activity currently rests on the combustion of fossil-based carbon, the principal source of such emissions. So an almost complete structural transformation of energy, transport, land use and industrial systems will be required to tackle the problem. Zenghelis argues that in the analysis of such a task, the focus of neoclassical economics on marginal market failures is wholly inadequate. We need rather to understand the processes of technological innovation and structural change. These are influenced both by 'path-dependence' - through which historic investments constrain future change-and by economic expectations. Strong and consistent policy-making can help shift investment towards tipping points when innovation may be driven rapidly in a low-carbon direction.

Carlota Perez notes that structural change of this kind has happened before. From the original industrial revolution based on water power and mechanisation, through the ages of coal and steam, steel and railways, automobiles and mass production, and latterly information and communications technologies (ICT), the modern world has witnessed distinct waves of technological revolution. Each of these has followed a pattern, both in the diffusion of the new technologies and products and in the response of the financial system and government policy-making. Perez argues that there is now huge potential to combine the further development of ICT with environmental technologies which radically reduce the carbon and material content of production and consumption. The result would be a new wave of growth which would simultaneously reduce environmental damage, provide new sources of employment and potentially reduce inequalities. Arguing for a range of policies to accelerate such a transition, including a shift in the burden of taxation from labour and profit to energy and resources, Perez sees this both leading to, and drawing on, a redefined, greener vision of the 'good life', in both developed and developing countries.

\section{Beyond market failure: towards a new approach}

Each chapter of the book approaches its subject in a different way. In commissioning them we wanted to reflect a variety of perspectives, both on the nature of the problems of modern capitalism and in the economics required to address them. The authors are responsible only for their own 
chapters: we did not seek, and do not claim, that they all agree with one another. Nevertheless, their critiques have many elements in common. Each challenges an important aspect of orthodox economic theory and policy prescription.

By 'orthodox' we mean the view that dominates public debate about economic policy. Within the academic discipline of economics there are lively arguments about many aspects of theory and policy. But mainstream economic discourse rests to a powerful extent on a very simple underlying conception of how capitalism works. This is that capitalism is an economic system characterised by competitive markets. In these markets privately owned companies, seeking to make profits for their shareholders, compete with one another to supply goods and services to other businesses and freely choosing consumers. In individual markets, neoclassical theory (on which the orthodox view is based) holds that such competition drives economic efficiency, which in turn maximises welfare. Markets are assumed to tend towards equilibrium, while businesses are assumed to be fundamentally alike, analysed as 'representative agents' constrained to act in the same ways by the external pressures of the market. At the level of the economy as a whole, it is competition between firms which is believed to generate innovation, and therefore leads to long-run economic growth.

The orthodox model understands that markets do not always work well. It therefore uses the concept of 'market failure' to explain why suboptimal outcomes occur and how they can be improved. Markets fail under various circumstances: when firms have monopolistic power which restricts competition; when there are information asymmetries between producers and consumers; when there are 'externalities' or impacts on third parties which are not properly reflected in market prices; and where public and common goods exist whose benefits cannot be captured by individual producers or consumers. ${ }^{36}$ The propensity of real-world markets to fail in these various ways means that 'free' markets do not maximise welfare. So the theory of market failure provides a rationale for government intervention. Public policy should seek to 'correct' market failures-for example by promoting competition; by requiring information about goods and services to be more widely available; by forcing economic actors to pay for externalities through means such as pollution taxes; and by providing or subsidising public goods.

At the same time, the orthodox view emphasises that it is not only markets which fail; governments do too. Even well-meaning ones can intervene badly, creating outcomes worse than if they had left markets alone-not least because private actors often adjust their behaviour to compensate. And public institutions are never disinterested - they develop goals and incentives of their own which may not reflect the general welfare of society as a whole. So public policy interventions always have to balance the goal of correcting market failures with the risk of generating government failures which outweigh them. ${ }^{37}$ 
Broadly speaking, it is this general model of capitalism which underpins most public economic commentary and policy-making today. And it leads to some familiar policy conclusions. Chief among these is that markets generally produce positive outcomes which increase welfare, and should therefore be allowed to operate without much interference wherever possible. A basic regulatory framework of employment, consumer and environmental protection is required to correct for clear externalities and information asymmetries; but governments should not seek to direct markets or shape the businesses which operate in them. The 'invisible hand' of the market knows best, generating the highest welfare-producing activities where firms seek to maximise value for their shareholders. Even where the market might seem to get it wrong, governments cannot presume to know better. So governments should be extremely wary of seeking to 'pick winners' through industrial and innovation policy; of seeking to push banks and other financial institutions to make specific forms of investments; or of investing in the private economy themselves. Public investment-particularly if funded by borrowing - will simply 'crowd out' private investment. Governments should seek to use competitive private enterprise to deliver public utilities and services wherever possible. Getting the public finances into balance should be the overwhelming priority of fiscal policy. Taxation is necessary; but because it tends to disincentivise wealth creation and work, it should be kept as low as possible. Within each of these propositions lurks many a disagreement among academic economists, often informed by subtly complex theory and detailed empirical evidence. But it is not hard to find these views expressed in public debate; and they have dominated the practice of policy-making over recent years.

The orthodox model provides an attractively simple framework for thinking about economics and policy. It combines the mathematical elegance of neoclassical microeconomics with plausible claims about the macroeconomy. The fact that many of the policy prescriptions which follow from it favour those in positions of incumbent economic power has given it a powerful grip on public discourse.

But it's not an adequate model for understanding how capitalism works. For markets are not simple structures which behave in the ways set out in economics textbooks; and 'market failure' is not a helpful concept for analysing capitalism's major problems or how to address them. These idealised theories assume away many of capitalism's key features, or treat them as 'imperfections' rather than structural, systemic characteristics. They ignore much of the evidence on how different economies actually function, and when and why they have performed well or badly. None of the key problems which Western capitalism has experienced over recent decadesweak growth and financial instability, declining investment and financialisation, the stagnation of living standards and rising inequality, dangerous environmental risk - are explained by them.

Capitalist economies are not theoretical abstractions but complex and dynamic systems, embedded in specific societies, as well as in natural 
environments governed by biophysical laws. They are formed of multiple relationships between real and heterogeneous economic actors whose behaviour is not that of idealised 'representative agents', but arises from their particular characteristics and choices in different circumstances. These relationships give rise not to equilibrium, but to dynamic patterns of growth and change. The macroeconomic outcomes they generate are more than simply the sum of their microeconomic parts. Their problems are not failures of markets which 'normally' succeed, but arise from fundamental characteristics and structures. So to understand how they work, and to explain how policy can help them work better, we need a much richer approach.

Fortunately, there are plenty of resources within economics with which to do this. For these characteristics of capitalist economies are hardly revelatory. They have been analysed in theory and documented in practice for more than a hundred years of economic scholarship. They underlie the work of some of the greatest economists of the past century - such as Karl Polanyi, Joseph Schumpeter and John Maynard Keynes - and of the more recent schools of evolutionary, institutional and post-Keynesian economics. As the separate chapters in this book show, analysis based on these foundations can generate searching critiques of current policy, and powerful alternative perspectives.

Three key insights underpin a rethinking of capitalism in these ways.

First, we need a richer characterisation of markets and the businesses within them. It is not helpful to think of markets as pre-existing, abstract institutions which economic actors (firms, investors and households) 'enter' to do business, and which require them, once there, to behave in particular ways. Markets are better understood as the outcomes of interactions between economic actors and institutions, both private and public. These outcomes will depend on the nature of the actors (for example, the different corporate governance structures of firms), their endowments and motivations, the body of law and regulation and cultural contexts which constrain them and the specific nature of the transactions which take place. Markets are 'embedded' in these wider institutional structures and social, legal and cultural conditions. ${ }^{38}$ In the modern world, as Polanyi pointed out, the concept of a 'free' market is a construct of economic theory, not an empirical observation. ${ }^{39}$ Indeed, he observed that the national capitalist market was effectively forced into existence through public policy-there was nothing 'natural' or universal about it. ${ }^{40}$

The orthodox notion of competition between firms is equally misleading. Many of the most important markets in modern capitalism are oligopolistic in form, characterised by economies of scale and 'network effects' that lead to concentration and benefit incumbents. But even where there is greater competition, capitalist businesses are not all the same, forced to behave in similar ways by the external forces of 'the market'. On the contrary, as Lazonick shows, what we actually observe is persistent heterogeneity, both in businesses' internal characteristics and in their reactions to different 
market circumstances. Given that they must compete through innovation, this is hardly surprising. As evolutionary economics has emphasised, this heterogeneity is not a short-run transition towards a world of similar actors, but a long-run feature of the system. ${ }^{41}$ Different norms and routines combine to generate different behaviours and outcomes.

In fact, the evidence shows the particular importance of ownership and governance structures. Over the past thirty years the orthodox view that the maximisation of shareholder value would lead to the strongest economic performance has come to dominate business theory and practice, in the US and UK in particular. ${ }^{42}$ But for most of capitalism's history, and in many other countries, firms have not been organised primarily as vehicles for the short-term profit maximisation of footloose shareholders and the remuneration of their senior executives. Companies in Germany, Scandinavia and Japan, for example, are structured both in company law and corporate culture as institutions accountable to a wider set of stakeholders, including their employees, with long-term production and profitability their primary mission. They are equally capitalist, but their behaviour is different. Firms with this kind of model typically invest more in innovation than their counterparts focused on short-term shareholder value maximisation; their executives are paid smaller multiples of their average employees' salaries; they tend to retain for investment a greater share of earnings relative to the payment of dividends; and their shares are held on average for longer by their owners. And the evidence suggests that while their shortterm profitability may (in some cases) be lower, over the long term they tend to generate stronger growth. ${ }^{43}$ For public policy, this makes attention to corporate ownership, governance and managerial incentive structures a crucial field for the improvement of economic performance.

In short, markets are not idealised abstractions, but concrete and differentiated outcomes arising from different circumstances. Contrary to the claims of orthodox economists that the laws of economics are like the laws of engineering: one set of laws works everywhere', ${ }^{44}$ there are in fact many different kinds of market behaviour, and several varieties of capitalism. ${ }^{45}$

The second key insight is that it is investments in technological and organisational innovation, both public and private, which are the driving force behind economic growth and development. The diffusion of such innovations across the economy affects not just patterns of production, but of distribution and consumption. It has been the primary source of improvements in productivity, and consequent rises in living standards, for the past 200 years. ${ }^{46}$ Thus a theory of how capitalist economies work must include at its centre the dynamics of innovation, understanding both the specific nature of the investments needed and the turbulent, non-equilibrium outcomes that result.

But this requires a much more dynamic and accurate understanding of how innovation occurs than is provided by the orthodox economic theories of imperfect competition. Drawing on Schumpeter's original analysis of the 
processes of 'creative destruction', ${ }^{47}$ modern evolutionary economics has done much to explain how firms operate with bounded rationality in circumstances of uncertainty, where markets tend towards disequilibrium and change is path-dependent. Growth results from the co-evolution of technologies, firms and industry structures and the social and public institutions which support them, connected by complex feedback processes. ${ }^{48}$

Promoting innovation therefore requires attention to be paid to each of these elements. The economy needs firms with risk-taking management cultures and incentives which reward long-run perspectives, rather than those, as Haldane notes, focused largely on short-term financial returns. Innovation requires very specific forms of finance: patient, long-term and committed. As Griffith-Jones and Cozzi argue, this creates a particular role for public banks, able to steer finance towards long-run projects, leverage private capital and stimulate multiplier effects. Taxation policies need to incentivise long-term investment.

Critically, as Mazzucato shows, innovation also needs well-funded public research and development institutions and strong industrial policies. These need to be directed across the entire innovation chain, not only in the classic 'public good' area of basic science. A crucial recognition is that innovation has not only a rate, but also a direction. ${ }^{49}$ Historically, that direction has often been determined by 'mission-oriented' public policies, which have steered both public and private investments into new fields. During the mass production era, as Perez notes, it was policies around suburbanisation that allowed the new technologies of mass production to be fully diffused and deployed. Mazzucato observes that public funding drove both the IT revolution and other fields such as bio- and nano-technologies and today's green technologies. ${ }^{50}$ Each of these has involved both supply-side and demandside policies, in which new markets as well as new products have been created and public investment has 'crowded in' private.

By setting societal missions, and using their own resources to co-invest with long-term capital, governments can do far more than 'level the playing field', as the orthodox view would allow. They can help tilt the playing field towards the achievement of publicly chosen goals. Just as the creation of the welfare state in the postwar period, and the information technology revolution in the decades around the turn of the century, unleashed new waves of economic growth and widened prosperity, so new missions today have the potential to catalyse new innovation and investment. Foremost among them must be the transformative challenge of reducing and eventually eliminating greenhouse gas emissions to limit dangerous climate change, and of constraining the economy's wider environmental impacts within biophysical boundaries. As Perez argues, there is particular potential for such a 'green' direction, allied to the continuing development of information and communications technologies, to drive a new wave of structural transformation and growth. 
Recognition of the role of the public sector in the innovation process informs the third key insight. This is that the creation of economic value is a collective process. Businesses do not create wealth on their own. No business today can operate without the fundamental services provided by the state: schools and higher education institutions, health and social care services, housing provision, social security, policing and defence, the core infrastructures of transport, energy, water and waste systems. These services, the level of resources allocated to them and the type of investments made in them, are crucial to the productivity of private enterprises. The private sector does not 'create wealth' while taxpayer-funded public services 'consume' it. The state does not simply 'regulate' private economic activity. Rather, economic output is co-produced by the interaction of public and private actors-and both are shaped by, and in turn help to shape, wider social and environmental conditions.

Keynes' analysis of the business cycle was crucial in this regard. ${ }^{51}$ His key insight was that private investment was both too volatile and too procyclical. It reinforces its own tendencies both to boom and slump. Government investment is thus needed not just to stabilise aggregate demand when spending is too low, but also to stimulate the 'animal spirits' of the business sector, which invests only when it is confident of future areas of growth. This point is about much more than the herd and bandwagon behaviour of the financial markets, as some have interpreted it. ${ }^{52}$ It makes the fundamental case for public investment as a means of creating economic opportunities and thereby increasing the willingness of firms to invest. As Zenghelis argues, the creation of expectations about future growth is a crucial role for government, and not just during downturns. It is why mission-oriented innovation policy - bringing Keynes and Schumpeter together-has such an important role to play in driving stronger economic performance. Indeed, Keynes argued that the 'socialisation of investment' - which, as Mazzucato suggests, could include the public sector acting as investor and equityholder-would provide more stability to the investment function and hence to growth. ${ }^{53}$

It is because public expenditure is critical to the co-production of the conditions for growth, as Kelton highlights, that the austerity policies which have reduced it in the period since the financial crash have proved so futile, increasing rather than diminishing the ratio of debt to GDP. And as Wray and Nersisyan emphasise, the endogenous nature of money created by 'keystrokes' in the banking system gives governments far greater scope to use fiscal policy in support of economic growth than the orthodox approach allows.

So the size and functions of the state matter profoundly to the performance of capitalist economies. In orthodox economic commentary it is frequently asserted that the role of the public sector should be minimised in order to free private enterprise from the 'dead hand' of regulation and the perverse impact of 'crowding out'. In fact, successful economies have almost 
all had states actively committed to their development. ${ }^{54}$ This is not just about the role of the state in providing or co-investing in infrastructure (as is sometimes conceded even by those otherwise sceptical of public investment), though this is indeed important. Its role in innovation is also key, as we have seen. At the same time, the development of a skilled and adaptive labour force requires deep investment in education, training, health, childcare and social care. These functions cannot simply be outsourced or privatised-as Crouch shows, when this is done the goal of greater competition almost always degenerates into private oligopoly, where public purpose is lost, and corporate political influence increases. We need to acknowledge, rather, the interdependence of private enterprise and the public sector; of market and non-market activities.

This has an important implication for the role of taxation. The orthodox economic view characterises taxation as an essentially negative activity in which the value generated by private firms is confiscated by the state. But understanding the role of the public sector in the co-production of economic output allows a more profound perspective. Taxation is the means by which economic actors pay the public sector for its contribution to the productive process. The orthodox model claims that reducing the share of taxation in overall economic output will tend to strengthen growth. If taxation is used productively by an active public sector, the opposite can be the case.

The collective nature of capitalist production makes the distribution of income and wealth an important variable for growth. In the orthodox model the rewards to labour and capital are believed to reflect their (marginal) productivity. But as Stiglitz argues, this theory cannot explain the dramatic growth in inequality over recent decades. It is evident, rather, that shareholders and senior executives-particularly in the financial sector-are extracting unearned rent from the value firms produce. And as Thomas Piketty has shown, the inheritance of capital (particularly land and property), whose increase in value outpaces that of the economy as a whole, skews the overall distribution of wealth far away from any notion of earned productivity. ${ }^{55}$ This has a profound effect on the fairness and inclusivity of today's economies. But it also negatively impacts on growth itself. There is striking evidence - now gathered and acknowledged by the OECD and IMF - that economies with more equal distributions of income and wealth have stronger and more stable economic growth than those with greater inequality. ${ }^{56}$ Redistributive policies which reduce inequality are found to have in general a positive impact on growth. ${ }^{57}$

This creates a powerful case for the rebalancing of the distribution of earnings between capital and labour. Employees have in effect become too weak, as trade unions have lost powers and membership, and deregulated, 'flexible' labour markets have allowed employers to bargain wages and working conditions down. Crucially, as experience of legal minimum wages has shown, raising wages tends to force firms to invest in improving productivity, which strengthens economic performance. ${ }^{58}$ Public policy 
therefore has an important role in regulating labour markets, promoting both trade union membership and employee ownership of capital, and managing markets in housing and land. It should also ensure progressive tax systems: of wealth as well as income, and of corporate as well as individual taxation.

One further aspect of co-production, with important distributional implications, is also critical. All economies operate within biophysical systems. From an ecological point of view, economic activity generates value by using material resources and energy which are subsequently returned to the environment as waste, in a thermodynamically more disordered (entropic) state. ${ }^{59}$ Economic growth can derive from expanding the use of biophysical resources, or from an increase in the economic value generated per unit of throughput. Today, with many of the natural environment's biophysical functions at or close to their safe limits, it powerfully matters - not least to the distribution of wealth between present and future generations - which of these predominates. In the context of dangerous climate change, as Zenghelis argues, the centrality of carbon to industrial economies makes an understanding of structural change - not just corrections to marginal market failures - particularly vital to economic analysis.

These three insights therefore have profound implications for how we think about economic policy-making. Public policies are not 'interventions' in the economy, as if markets existed independently of the public institutions and social and environmental conditions in which they are embedded. The role of policy is not one simply of 'correcting' the failures of otherwise free markets. It is rather to help create and shape markets to achieve the co-production, and the fair distribution, of economic value. Economic performance cannot be measured simply by the short-term growth of GDP, but requires better indicators of long-term value creation, social well-being, inequality and environment sustainability. ${ }^{60}$

Western capitalism has not been functioning well in recent years. Mainstream economic policies, reflecting an outdated economic orthodoxy, have proved themselves unable to set it on a new course. We hope the ideas set out in this book show that there is nothing inevitable about this failure. A more innovative, sustainable and inclusive economic system is possible. But it will require fundamental changes in our understanding of how capitalism works, and how public policy can help create and shape a different economic future.

\section{Notes}

1 http:/ /www.telegraph.co.uk/news/uknews/theroyalfamily/3386353/The-Queenasks-why-no-one-saw-the-credit-crunch-coming.html (accessed 12 April 2016).

2 Following the Queen's question, the British Academy held a seminar to enquire into how it should be answered, and subsequently wrote to the sovereign to explain their conclusions. See http://www.britac.ac.uk/news/newsrelease-econo my.cfm (accessed 12 April 2016). 
3 S. Verick and I. Iyanatul, The Great Recession of 2008-2009: Causes, Consequences and Policy Responses, Discussion Paper No 4934, Bonn, Institute for the Study of Labor, 2010.

4 IMF, World Economic Outlook: Uneven Growth-Short- and Long-Term Factors, Washington, DC, International Monetary Fund, April 2015, p. 171. The three advanced economies that saw real GDP growth in 2009 were Australia, Korea and Israel.

5 International Monetary Fund, International Labour Organization, The Challenges of Growth, Employment and Social Cohesion, 2010, http://www.osloconference2010. org/discussionpaper.pdf (accessed 12 April 2016).

6 Wall Street Aristocracy Got \$1.2 Trillion in Secret Loans, Bloomberg, 11 August 2011, http: / / www.bloomberg.com/news/articles/2011-08-21/wall-street-aristocracygot-1-2-trillion-in-fed-s-secret-loans (accessed 12 April 2016); National Audit Office, Taxpayer Support for UK Banks, FAQs, https://www.nao.org.uk/highlights/tax payer-support-for-uk-banks-faqs/ (accessed 12 April 2016). These figures relate to peak exposure on a single day. In the US, the cumulative amount committed by the Federal Reserve to shoring up the financial system has been calculated at between $\$ 7.77$ trillion by Bloomberg-Secret Fed Loans Gave Banks $\$ 13$ Billion Undisclosed to Congress, Bloomberg Markets, 28 November 2011, http://www.bloomberg.com/ news/articles/2011-11-28/secret-fed-loans-undisclosed-to-congress-gave-banks-13-bil lion-in-income (accessed 12 April 2016) - and $\$ 29$ trillion by James Felkerson, \$29,000,000,000,000: A Detailed Look at the Fed's Bailout by Funding Facility and Recipient, Working Paper No. 698, Levy Economics Institute of Bard College, 2011, http:// www.levyinstitute.org/pubs/wp_698.pdf (accessed 12 April 2016).

7 OECD, General government deficit (indicator), 2016, doi: 10.1787/77079edb-en (accessed 12 April 2016).

8 Testimony to the Congressional Committee on Oversight and Government Reform, 23 October 2008, https://www.gpo.gov/fdsys/pkg/CHRG-110hhrg 55764/html/CHRG-110hhrg55764.htm (accessed 12 April 2016).

9 R. J. Shiller, Irrational Exuberance, Princeton, NJ, Princeton University Press, 2000.

10 C. Reinhart and K. Rogoff, 'Growth in a time of debt', American Economic Review, vol. 100, no. 2, 2010, pp. 573-8.

11 L. Laeven and F. Valencia, Systemic Banking Crises: A New Database, IMF Working Paper No. 224, November 2008.

12 J. A. Turner, Between Debt and the Devil: Money, Credit, and Fixing Global Finance, Princeton and Oxford, Princeton University Press, 2016.

13 Unemployment was lower in 2014 than in 2007 in five OECD countries: Chile, Germany, Israel, Japan and Poland. Averaged across OECD countries, unemployment was at 5.6 per cent in 2007, peaked at 8.3 per cent in 2010 and was at 7.3 per cent in 2014. For EU28 countries, unemployment was lowest in 2008 at 7 per cent, and continued rising to a peak of 10.8 per cent in 2013. OECD, Unemployment rate (indicator), 2016, doi: 10.1787/997c8750-en (accessed 12 April 2016).

14 Low Pay Commission, National Minimum Wage, Low Pay Commission Report 2013, Cm 8816, London, The Stationery Office, 2014.

15 W. Lazonick, 'Profits without prosperity', Harvard Business Review, vol. 92, no. 9, 2014, pp. 46-55.

16 OECD, OECD Compendium of Productivity Indicators 2015, Paris, OECD Publishing, 2015, doi:10.1787/pdtvy-2015-en (accessed 12 April 2016). 
17 R. J. Gordon, Is US Economic Growth Over? Faltering Innovation Confronts the Six Headwinds, Centre for Economic Policy Research, Policy Insight No. 63, September 2012, http://www.cepr.org/sites/default/files/policy_insights/PolicyInsight63. pdf (accessed 12 April 2016).

18 See for example L. H. Summers, 'U.S. economic prospects: secular stagnation, hysteresis, and the zero lower bound', Business Economics, vol. 49, no. 2, 2014, pp. 65-73, http://larrysummers.com/wp-content/uploads/2014/06/NABE-speechLawrence-H.-Summers1.pdf (accessed 12 April 2016); C. Teulings and R. Baldwin (eds), Secular Stagnation: Facts, Causes and Cures, London, CEPR Press, 2014, http:/ / voxeu.org/sites/default/files/Vox_secular_stagnation.pdf (accessed 12 April 2016).

19 Real median US household income in 2014 was $\$ 53,657$ compared with $\$ 52,623$ in 1990 (using 2014 CPI-U-RS Adjusted Dollars). Source: US Bureau of the Census, made available by the Federal Bank of St Louis, https://research.stlouisfed.org/fred2/series/MEHOINUSA672N (accessed 12 April 2016).

20 E. Stockhammer, Why Have Wage Shares Fallen? A Panel Analysis of the Determinants of Functional Income Distribution, Geneva, International Labour Office, 2013. The wage share is adjusted to take account of self-employment. 'Advanced economies' includes all high-income OECD countries, with the exception of South Korea.

21 ILO, Global Wage Report 2012/13, Geneva, International Labour Organisation, 2013.

22 OECD, World Economic Outlook: Spillovers and Cycles in the Global Economy, Paris, OECD Publishing, 2007, Figure 5.15.

23 OECD, Income Inequality: The Gap between Rich and Poor, Paris, OECD Publishing, 2015.

24 T. Piketty and E. Saez, 'Income inequality in the United States, 1913-1998', Quarterly Journal of Economics, vol. 118, no. 1, 2003, pp. 1-39, Tables A3 and A6-Updated version downloaded from http://eml.berkeley.edu/ saez/. Figures are in real 2013 dollars and include capital gains (accessed 12 April 2016).

25 OECD, OECD Employment Outlook 2012, Paris, OECD Publishing, 2012, http:// dx.doi.org/10.1787/empl_outlook-2012-en (accessed 12 April 2016). Figures relate to countries for which data is available.

26 ILO, Global Wage Report 2010/11, Geneva, International Labour Organisation, 2010, Figure 20.

27 OECD, Youth unemployment rate (indicator), 2016, doi: 10.1787/c3634df7-en (accessed 12 April 2016).

28 OECD, In It Together: Why Less Inequality Benefits Us All, Paris, OECD Publishing, 2015, Figure 4.1.B, http://dx.doi.org/10.1787/888933208028 (accessed 12 April 2016).

29 Ibid, http:/ /dx.doi.org/10.1787/888933207711 (accessed 12 April 2016).

30 Data from http://piketty.pse.ens.fr/files/capital21c/en/xls/, Figures 10.3 and 10.5, and Table S10.1 (accessed 12 April 2016).

31 J. Rockström et al., 'A safe operating space for humanity', Nature, no. 461, 24 September 2009, pp. 472-5, http://www.nature.com/nature/journal/v461/ n7263/full/461472a.html (accessed 12 April 2016); W. Steffen et al., 'Planetary boundaries: guiding human development on a changing planet', Science, vol. 347, no. 6223, 13 February 2015, http://science.sciencemag.org/content/347/6223/ 1259855 (accessed 12 April 2016).

32 Intergovernmental Panel on Climate Change, Climate Change 2014: Impacts, Adaptation, and Vulnerability: Summary for Policymakers, Cambridge and New York, 
Cambridge University Press, 2014, https://www.ipcc.ch/report/ar5/wg2/ (accessed 12 April 2016).

33 The first assessment report of the Intergovernmental Panel on Climate Change was published in 1990. See https://www.ipcc.ch/publications_and_data/publica tions_ipcc_first_assessment_1990_wg1.shtml (accessed 12 April 2016).

34 T. O. Wiedmann et al., 'The material footprint of nations', Proceedings of the National Academy of Sciences of America, vol. 112, no. 20, 2015, pp. 6271-6, doi:10.1073/pnas.1220362110 (accessed 12 April 2016).

35 There is a lively debate among monetary theorists over whether governments, as opposed to central banks, do in practice create new money through government spending, or whether they have to acquire bank-credit money through taxation or borrowing prior to government spending. In practice, in the UK and European Union, legal and institutional arrangements are designed to prevent the expansion of the money supply through government spending. But many economists would accept the fundamental argument that monetary expansion is key to achieving sufficient nominal demand growth, and that state money creation may be preferable to private bank credit creation. For a good discussion, see J. A. Turner, Between Debt and the Devil: Money, Credit, and Fixing Global Finance, Princeton, NJ, Princeton University Press, 2015.

36 The original account of market failure is in K. Arrow, An Extension of the Basic Theorems of Classical Welfare Economics, paper presented at the Second Berkeley Symposium on Mathematical Statistics and Probability, Berkeley, 1951.

37 G. Tullock, A. Seldon and G. L. Brady, Government Failure: A Primer in Public Choice, Washington, DC, Cato Institute, 2002.

38 P. B. Evans, Embedded Autonomy: States and Industrial Transformation, Princeton, NJ, Princeton University Press, 1995.

39 K. Polanyi, The Great Transformation: The Political and Economic Origins of Our Time, Boston, MA, Beacon Press, 2001 [1944].

40 As Polanyi put it: 'The road to free markets was opened and kept open by an enormous increase in continuous, centrally organized and controlled interventionism ... Administrators had to be constantly on the watch to ensure the free working of the system.' Ibid, p. 144.

41 R. R. Nelson and S. G. Winter, An Evolutionary Theory of Economic Change, Cambridge, MA, Harvard University Press, 2009.

42 W. Lazonick and M. O'Sullivan, 'Maximizing shareholder value: a new ideology for corporate governance', Economy and Society, vol. 29, no. 1, 2000, pp. 13-35.

43 W. Hutton, How Good We Can Be: Ending the Mercenary Society and Building a Great Country, London, Abacus, 2015.

44 Lawrence Summers, October 1991, when Chief Economist at the World Bank; cited by M. Ellman, 'Transition economies', in H.-J. Chang, ed., Rethinking Development Economics, London and New York, Anthem Press, 2003, pp. 179-98 (p. 197).

45 P. A. Hall and D. Soskice, eds., Varieties of Capitalism. The Institutional Foundations of Comparative Advantage, Oxford, Oxford University Press, 2001.

46 C. Perez, Technological Revolutions and Financial Capital: The Dynamics of Bubbles and Golden Ages, London, Edward Elgar, 2002.

47 J. A. Schumpeter, Capitalism, Socialism, and Democracy, 3rd edn, New York, Harper, 1962 [1942].

48 Nelson and Winter, An Evolutionary Theory of Economic Change; see also R. Nelson, Economic Development from the Perspective of Evolutionary Economic Theory, 
GLOBELICS Working Paper No. 2007-02, 2007, http://dcsh.xoc.uam.mx/eii/ globelicswp/wpg0702.pdf (accessed 12 April 2016).

49 A. Stirling, "Opening up" and "closing down" power, participation, and pluralism in the social appraisal of technology', Science, Technology and Human Values, vol. 33, no. 2, 2008, pp. 262-94 (accessed 12 April 2016).

50 D. Foray, D. C. Mowery and R. R. Nelson, 'Public R\&D and social challenges: what lessons from mission R\&D programs?' Research Policy, vol. 41, no. 10, 2012, pp. 1697-702; M. Mazzucato, 'From market fixing to market-creating: a new framework for innovation policy', forthcoming in special issue of Industry and Innovation: 'Innovation Policy - can it make a difference?', 2016, available at doi:10.1080/13662716.1146124 (accessed 12 April 2016).

51 J. M. Keynes, The General Theory of Employment, Interest and Money, London, Macmillan, 2007 [1936].

52 Shiller, Irrational Exuberance.

53 'I expect to see the State ... taking an ever greater responsibility for directly organising investment ... I conceive, therefore, that a somewhat comprehensive socialisation of investment will prove the only means of securing an approximation to full employment.' J. M. Keynes, The Collected Writings of John Maynard Keynes, vol. 7, Cambridge, Cambridge University Press, 1973, pp. 164, 378.

54 H.-J. Chang, Globalization, Economic Development and the Role of the State, London, Zed Books, 2002.

55 T. Piketty, Capital in the 21st Century, Cambridge, MA, Harvard University Press, 2014.

56 A. Berg and J. D. Ostry, Inequality and Unsustainable Growth: Two Sides of the Same Coin?, International Monetary Fund Staff Discussion Note No. 11/08, April 2011, https://www.imf.org/external/pubs/ft/sdn/2011/sdn1108.pdf (accessed 12 April 2016); F. Cingano, Trends in Income Inequality and Its Impact on Economic Growth, OECD Social, Employment and Migration Working Papers, No. 163, December 2014, http://www.oecd.org/els/soc/trends-in-income-inequality-and-its-impact-oneconomic-growth-SEM-WP163.pdf (accessed 12 April 2016).

57 J. D. Ostry, A. Berg and C. G. Tsangarides, Redistribution, Inequality and Growth, IMF Staff Discussion Note, SDN 14/02, 2014, https://www.imf.org/external/ pubs/ft/sdn/2014/sdn1402.pdf (accessed 12 April 2016). For a wider discussion on the relationship between economic performance, well-being and inequality, see R. G. Wilkinson and K. Pickett, The Spirit Level: Why More Equal Societies Almost Always Do Better, London, Allen Lane, 2009.

58 R. Riley and C. Rosazza Bondibene, Raising the Standard: Minimum Wages and Firm Productivity, NIESR Discussion Paper 449, National Institute for Economic and Social Research, 2015, http://www.niesr.ac.uk/sites/default/files/publi cations /Minimum \%20wages $\% 20$ and $\% 20$ firm $\% 20$ productivity $\% 20$ NIESR $\% 20$ DP $\%$ 20449.pdf (accessed 12 April 2016).

59 N. Georgescu-Roegen, The Entropy Law and the Economic Process, Cambridge, MA, Harvard University Press, 1971; M. Jacobs, The Green Economy, London, Pluto Press, 1991; H. E. Daly and J. Farley, Ecological Economics: Principles and Applications, Washington, Island Press, 2011.

60 J. E. Stiglitz, A. Sen and J. P. Fitoussi, Report by the Commission on the Measurement of Economic Performance and Social Progress, Paris, Commission on the Measurement of Economic Performance and Social Progress, 2010. 